\title{
Genetic progress with selection of Coffea canephora clones of superior processed coffee yield
}

\section{Dulcilene Oliveira da Silva ${ }^{1}$ Fábio Medeiros Ferreira ${ }^{1}$ Rodrigo Barros Rocha ${ }^{2^{*}}$ Marcelo Curitiba Espindula ${ }^{2}$ Victor Mouzinho Spinelli ${ }^{2}$}

${ }^{1}$ Instituto de Ciências Exatas e Tecnologia, Universidade Federal do Amazonas (UFAM), Itacoatiara, AM, Brasil.

${ }^{2}$ Empresa Brasileira de Pesquisa Agropecuária (Embrapa), Centro de Pesquisa Agroflorestal de Rondônia, 76815-800, Porto Velho, RO, Brasil. E-mail: rodrigo.rocha@embrapa.br. "Corresponding author.

\begin{abstract}
The aim of this study was to select Coffea canephora clones of superior processed coffee productivity based on the estimates of the genetic parameters and of genetic progress with the plant selection. For this, the production of processed coffee from 130 clones was evaluated from 2014 to 2016 in a clonal test, installed in randomized complete blocks with four plants per plot and six replications, spaced $3 \times 2 m$ at the experiment station Embrapa Rondonia in the municipality of Ouro Preto do Oeste - RO. The estimation of genetic parameters and prediction of genotypic values were performed using REML/BLUP procedure (Restricted Maximum Likelihood/Best Unbiased Linear Prediction). Estimates of the genetic parameters confirmed the predominance of the genetic component in the expression of this trait, indicating the possibility of obtaining gains with the plant selection. Genetic progress of processed coffee productivity from the selection of $10 \%$ of the best clones was $49.88 \%$, which is equivalent to an increase in average productivity from 42.57 bags.ha ${ }^{-1}$ to 66.95 bags. ha $^{-1}$. The use of the harmonic mean of the genetic values helped to identify the clones of superior performance, with higher adaptability and stability for the northern region of Brazil. Key words: Coffea canephora Pierre ex Froehner, REML/BLUP, genetic parameters.
\end{abstract}

Progresso genético com a seleção de clones de Coffea canephora para produção superior de café beneficiado

RESUMO: O objetivo desse trabalho foi mensurar o progresso genético da produtividade de café beneficiado a partir da seleção de clones de Coffea canephora, com a obtenção de estimativas dos parâmetros genéticos e de ganhos com a seleção ao longo de três safras. Para isso, a produção de café beneficiado de 130 clones foi avaliada nas safras de 2014, 2015 e 2016 em ensaio clonal instalado em blocos completos casualizados, com quatro plantas por parcela e seis repetições, em espaçamento de $3 \times 2 \mathrm{~m}$ na estação experimental da Embrapa Rondônia no município de Ouro Preto do Oeste - RO. A estimação dos parâmetros genéticos e predição dos valores genotípicos foram realizadas utilizando procedimento REML/BLUP (máxima verossimilhança restrita/melhor predição linear não-viesada). As estimativas dos parâmetros genéticos quantificaram predominância do componente genético na expressão dessa característica, indicando a possibilidade de obtenção de ganhos com a seleção de plantas. O progresso genético da produtividade de café beneficiado com a seleção de $10 \%$ dos melhores clones foi de $49,88 \%$, que equivale a um incremento na produtividade média de 42,57 sacas. ha $a^{-1}$ para 66,95 sacas. ha ${ }^{-1}$. A média harmônica da performance relativa dos valores genotípicos (MHPRVG) permitiu identificar clones de desempenho superior estável em condições tropicais da região Amazônica. Palavras-chave: Coffea canephora Pierre ex Froehner, REML/BLUP, parâmetros genéticos.

\section{INTRODUCTION}

Coffea canephora is an allogamous, diploid plant species, which exhibits gametophytic self-incompatibility. It is native to the low forests of equatorial Africa (SOUZA et al., 2013), and has wide geographical distribution (BATISTA-SANTOS et al., 2011, PARTELLI et al., 2011; RAMALHO et al., 2014). In Brazil, it is responsible for approximately
$30 \%$ of the national coffee production. The state of Rondônia has the largest area of coffee plantations in the Amazon (92\% of the total production). Indeed, the state is the fifth largest coffee producer and the second largest $C$. canephora producer in Brazil, only second to Espírito Santo (CONAB, 2017).

Two botanical varieties of $C$. canephora are grown commercially (BERTHAUD \& CHARRIER, 1985). Robusta belongs to the Congolese group, native 
to Central Africa and characterized by larger size, larger leaves, and fruits, and higher resistance to nematodes and rust. The Conilon originated in West Africa is a shrub with elongated leaves, higher tolerance to drought and higher susceptibility to disease (SOUZA et al., 2015; MONTAGNON et al. 1992).

C. canephora breeding programs search for new methods and strategies to evaluate more materials in less time, thus, increasing the capacity to manipulate genetic variability (DUBBERSTEIN et al., 2017; RODRIGUES et al., 2016; ROCHA et al., 2015). Clone evaluation trials are one of the strategies for selection of high-yield clones also with favorable characteristics, such as higher uniformity of maturation, higher average bean size and higher adaptability to the tropical conditions of the Amazon region (RAMALHO et al., 2016; SOUZA et al., 2017; SANTOS et al., 2017).

Prediction of gain from selection of unrelated clones depends on accurately estimating genotypic variance. REML/BLUP (restricted maximum likelihood/best linear unbiased prediction) is currently the main procedure for the estimation of genetic parameters in perennial species, because it allows the prediction of genetic values considering fixed effects and unbalanced data (RESENDE, 2007). New analysis strategies have also been used to select superior clones with emphasis on the harmonic mean of the relative performance of genotypic values (RPGV), which allows the selection of plants with better performance and lower variation between harvests (RESENDE, 2007).

Lower biannual variation is as important as yield potential for the selection of clones with higher yield stability that maintain their superiority overtime. Since it is related to the minimum number of measurements necessary for accurate selection of superior genotypes, repeatability and maximum broad-sense heritability-allows quantifying the maintenance of clone superiority overtime (ROCHA et al., 2015).

The aim of the present study was to measure the genetic progress in processed coffee yield through selection of Coffea canephora clones over three harvests. Our purpose was to select clones with better yield performance and lower variation between harvests.

\section{MATERIALS AND METHODS}

\section{Field experiment}

A field trial was conducted to evaluate yield performance of 130 clones of botanical varieties
Conilon and Robusta, as well as Conilon $\times$ Robusta hybrids. The assay was conducted in December 2011, in the experimental field of Embrapa, in the municipality of Ouro Preto do Oeste, state of Rondônia (RO) $\left(10^{\circ} 37^{\prime} 03^{\prime \prime} \mathrm{S} ; 62^{\circ} 51^{\prime} 50^{\prime \prime} \mathrm{W}\right)$. The climate in this region is Aw (according to Köppen), tropical humid with a rainy season in summer (October to May) and a well-defined dry season in winter.

A completely randomized block design was used, with four plants per plot and $3 \times 2 \mathrm{~m}$ spacing. Processed coffee yield was evaluated for three harvests in 2014, 2015 and 2016. Crop management during the experiment was performed according to the recommendations for the state of Rondônia (MARCOLAN et al., 2009). Genotypic values of processed coffee yield were estimated based on bean yield, expressed as bags of processed coffee per hectare, calculated based on the weight of cherry coffee beans harvested per plot and the yield between cherry coffee and processed coffee, evaluated separately for each clone and harvest (RAMALHO et al., 2016).

\section{Biometric analyses}

Variance components were estimated using the REML method (restricted maximum likelihood), while genotypic values were estimated using the BLUP procedure (best linear unbiased prediction), using linear mixed models (RESENDE, 2007). Genetic values were estimated using the SelegenREML/BLUP software. The following linear mixed models (RESENDE, 2002) were considered: (1) $y=X b+Z g+e$, where: $y$ is the data vector; $X$ is the incidence matrix for the fixed block effects; $b$ is the block-effect vector, considered fixed; $Z$ is the incidence matrix for the random effect of individuals; $g$ is the genotypic-effects vector, considered random; $e$ is the random error vector. (2) $y=X m+Z g+W p+$ $e$, where $y$ is the data vector; $m$ is the measurementreplicate combination effect vector, considered fixed; $g$ is the genotypic effect vector, considered random; $p$ is the permanent environment effect vector considered random; $e$ is the random error vector. Assumptions about structures of averages and variances of vectors for the distribution of $y, g, e, p$ were the following: $y|b, V \sim N(X b, V) ; \mathbf{g}| \boldsymbol{\sigma}_{\mathrm{g}}^{2} \sim \mathbf{N}\left(\mathbf{0}, \boldsymbol{\sigma}_{\mathrm{g}}^{2}\right), \mathbf{p} \mid \mathbf{\sigma}_{\mathrm{p}}^{2} \sim \mathbf{N}\left(\mathbf{0}, \mathbf{I} \boldsymbol{\sigma}_{\mathrm{p}}^{2}\right)$, $\mathrm{e} \mid \boldsymbol{\sigma}_{\mathrm{e}}^{2} \sim \mathbf{N}\left(\mathbf{0}, \mathbf{I} \boldsymbol{\sigma}_{\mathrm{e}}^{2}\right)$. Covariances among all random effects were considered null.

Heritability, repeatability, and accuracy of selection are among the most important genetic parameters for the characterization of genetic control of traits and the efficiency of selection (CRUZ et al., 2014). Genetic gain 
was estimated as $\widehat{G}_{s}=\left(g_{1}-g_{0}\right)$, where $g_{1}$ is the mean of genotypic effects of the selected clones, while $g_{0}$ is the mean of genotypic effects of the unimproved population. In addition, RPGV for processed coffee yield was usIn addition, the harmonic mean of the genotypic values was used to select genotypes with superior genetic value and lower variation between harvests. This was done by using the following equation (RESENDE, 2007):

$$
\bar{X}_{H}=\frac{n}{\sum_{i=1}^{n} \frac{1}{R P G V_{i}}}
$$

Where, $\bar{X}_{H}$ is the harmonic mean of the genotypic values; $\mathrm{n}$ is the number of agricultural years, and RPGVi are the genotypic values expressed as a proportion of the overall average for each year (for i between 1 and 3) (RESENDE, 2007).

\section{RESULTS AND DISCUSSION}

Higher genotypic variance than environmental variance was observed in each harvest. This indicated the predominance of the clone effect on the expression of processed coffee yield, resulting from different gene expression among plants (Table 1). Higher estimated genotypic variance than environmental variance for $C$. canephora has been previously reported (FERRÃO et al., 2008; RAMALHO et al., 2016).

The experimental coefficient of variation $\left(\mathrm{CV}_{\mathrm{e}}\right)$ is used to quantify experimental quality. $\mathrm{CV}_{\mathrm{e}}$ varied between $28.71 \%$ and $33.01 \%$, for the three harvests evaluated. These values are higher than previously reported by FERRÃO et al. (2008) (16.92\% and $26.40 \%$ ) and RAMALHO et al. (2016) (19.70\%to $26.25 \%)$. The genotypic coefficient of variation $\left(\mathrm{CV}_{\mathrm{g}}\right)$ was considered an indicator of gain from selection, since the higher the $\mathrm{CV}_{\mathrm{g}}$, the more heterogeneous are the genotypes evaluated (CRUZ et al., 2014). $\mathrm{CV}_{\mathrm{g}}$ varied between $39.11 \%$ and $58.26 \%$ (Table 1), being close to the values observed by RAMALHO et al., (2016). Relative coefficients of variation $\left(\mathrm{CV}_{r}\right)$ close to or higher than 1 , indicated adequate conditions for genetic gain from selection (VENCOVSKY et al., 2012). In the present study, $\mathrm{CV}_{\mathrm{r}}$ was always higher than 1 (Table 1).

Estimated broad-sense heritability $\left(h_{\mathrm{g}}^{2}\right)$ varied between 0.47 and 0.77 , also indicating predominance of the genetic component on yield expression. This is in agreement with RAMALHO et al. (2016). The

Table 1 - Estimated genetic parameters of processed coffee grain yield (bags.ha ${ }^{-1}$ ) for Conilon coffee clones evaluated for three cropping seasons, in the experimental field of Embrapa Rondônia, located in the municipality of Ouro Preto do Oeste - RO.

\begin{tabular}{|c|c|c|c|c|}
\hline \multirow[t]{2}{*}{ Genetic parameters $^{\&}$} & \multicolumn{3}{|c|}{ 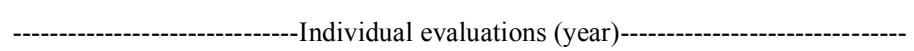 } & \multirow{2}{*}{$\begin{array}{l}\text { Joint evaluation } \\
2014 / 2015 / 2016\end{array}$} \\
\hline & $2013 / 14$ & $2014 / 15$ & $2015 / 16$ & \\
\hline $\mathrm{V}_{\mathrm{g}}$ & 198.94 & 440.62 & 575.60 & 277.07 \\
\hline$V_{\text {perm }}$ & - & - & - & 129.43 \\
\hline $\mathrm{V}_{\mathrm{e}}$ & 124.45 & 228.01 & 165.07 & 172.48 \\
\hline$V_{f}$ & 323.39 & 668.64 & 740.68 & 579.00 \\
\hline $\mathrm{h}_{\mathrm{g}}^{2 \#}$ & $0.61 \pm 0.08$ & $0.65 \pm 0.09$ & $0.77 \pm 0.10$ & $0.47 \pm 0.04$ \\
\hline $\mathrm{h}_{\mathrm{mc}}^{2}$ & 0.91 & 0.92 & 0.95 & 0.84 \\
\hline $\mathrm{Ac}_{\text {clon }}$ & 0.95 & 0.96 & 0.97 & - \\
\hline$c^{2}$ perm & - & - & - & 0.22 \\
\hline $\mathrm{CV}_{\mathrm{g}}(\%)$ & 41.74 & 39.91 & 58.26 & - \\
\hline $\mathrm{CV}_{\mathrm{e}}(\%)$ & 33.01 & 28.71 & 31.20 & - \\
\hline $\mathrm{CV}_{\mathrm{r}}$ & 1.26 & 1.39 & 1.86 & - \\
\hline PEV & 18.78 & 34.98 & 26.25 & - \\
\hline SEP & 4.33 & 5.91 & 5.12 & - \\
\hline $\mathrm{r}^{\$}$ & - & - & - & $0.70 \pm 0.05$ \\
\hline Overall average & 33.80 & 52.59 & 41.17 & 42.57 \\
\hline
\end{tabular}

${ }^{{ }^{k}} \mathrm{~V}_{\mathrm{g}}$ : genotypic variance; $\mathrm{V}_{\mathrm{e}}$ : residual variance; $\mathrm{V}_{\text {perm}}$ : permanent environmental effects variance; $\mathrm{V}_{\mathrm{f}}$ : individual phenotypic variance; $\mathrm{h}_{\mathrm{g}}^{2}$ : individual heritability sensu lato; $\mathrm{h}_{\mathrm{mc}}^{2}$ : overall average clone heritability; Ac clon: selective accuracy; $\mathrm{c}^{2}$ perm:coefficient of determination of the permanent environmental effects; $\mathrm{CV}_{\mathrm{gi}}$ : individual genotypic coefficient of variation; $\mathrm{CV}_{\mathrm{e}}$ : residual coefficient of variation; $\mathrm{CVr}=$ $\mathrm{CV}_{\mathrm{g}} / \mathrm{CV}_{\mathrm{e}}$,relative coefficient of variation; PEV: variance of prediction error of genotypic values; SEP: predicted genotypic value standard deviation; r: coefficient of repeatability; Overall average (genotypic) for the experiment, "Heritability sensu lato and respective standard deviation, ${ }^{\mathrm{s}}$ Repeatability and respective standard deviation. 
standard deviation for broad-sense heritability was considered a measure of the quality of estimations (Table 1). Standard deviations of up to $20 \%$ of estimated heritability indicate good estimation accuracy (RESENDE, 2002). The highest relationship between standard deviation and heritability was observed for the 2015 harvest (13.84\%), and the lowest for the joint analysis of the three harvests $(8.50 \%)$. Clone average heritability $\left(\mathrm{h}_{\mathrm{mc}}^{2}\right)$ varied little among the three harvests, and was higher thanfor all harvests.

The permanent effects coefficient of determination $\left(\mathrm{c}^{2}{ }_{\text {perm }}\right)$ was of a moderate magnitude (0.22), showing that the environmental variation from year to year was an important factor that affected the expression coffee yield. The estimated variance of permanent environmental effects (Vperm) corresponded to $22.35 \%$ of phenotypic variation, with plant differences observed among different cropping seasons (FERRÃO et al., 2008).

The estimated repeatability coefficient (r) was 0.70 . According to the classification by RESENDE (2002), this is a high value $(\rho \geq 0.60)$. RAMALHO et al. (2016) observed lower repeatability for grain yield $(\mathrm{r}=0.43)$ and FERRÃO et al. (2008) reported repeatability coefficients between 0.26 and 0.63 for $C$. arabica processed coffee yield. High accuracy (0.95 to 0.97 ) was observed for the evaluated harvests (Table 1), indicating that the predicted genetic values were close to the observed values, and that it is easier to select superior plants based on the grain yield.

A repeated measures analysis of the processed coffee yield was performed in order to determine the consistency of the relative position (order) of the clones throughout successive harvests (Table 2). For the three evaluated harvests, the coefficient of determination $\left(\mathrm{R}_{\mathrm{g}}^{2}\right)$ was 0.88 or $88 \%$, with high heritability $\left(h_{i m}^{2}=0.82\right)$, high accuracy $\left(\mathrm{AC}_{\text {clon }}=0.90\right.$ or $\left.90 \%\right)$ and an efficiency $11 \%$ higher, when compared to a single harvest. Coefficients of determination higher than $80 \%$ (and accuracy higher than $89 \%$ ) are considered adequate when a larger group of genotypes was selected (RESENDE, 2002). FONSECA et al. (2004) estimated repeatability for $C$. canephora yield based on the performance of 80 genotypes of the Conilon variety, in the state of Espírito Santo, and observed accuracy $\left(\mathrm{R}_{\mathrm{g}}^{2}\right)$ between $65.32 \%$ and $81.59 \%$ for four harvests, depending on the method used. Increasing the number of harvests from four to six, accuracy increased up to, between $73.84 \%$ and $86.92 \%$.

The harmonic mean of the genotypic values allowed to simultaneously select clones with superior performance, genotypic adaptability and productive stability (Table 3), i.e., it favored the selection of clones with superior genetic value and lower variation over the years (RESENDE, 2007). Clones 16R1C81, 535, 78, 167, 130, 453, 890, 482, 193, 194, 160, 909, and 533, stood out by showing higher productive potential in addition to higher stability and adaptability.

In the present study, annual average yield for the different genotypes varied between 33.80 and 52.59 bags.ha $^{-1}$, with an overall average of 42.57 bags.ha $^{-1}$ (Table 1). A selection intensity of $10 \%$ resulted in a genetic progress of $49.88 \%$, with selection of the same clones as selected by the RPGV method; although, with a different ranking (Table 3). This selection gain corresponds to an increase in overall average yield from 42.57 bags ha $^{-1}$ to 66.95 bags ha ${ }^{-1}$ over three years. Genetic progress decreased to $41.77 \%$ when $20 \%$ of the clones were selected and to $35.50 \%$ when $30 \%$ of

Table 2 - Genetic parameters and efficiency for the use of up to 10 harvests of processed coffee (bags.ha ${ }^{-1}$ ) from Conilon coffee clones, evaluated for three cropping seasons in the experimental field of Embrapa Rondonia, in the municipality of Ouro Preto do Oeste RO.

\begin{tabular}{|c|c|c|c|c|c|c|c|c|c|c|}
\hline \multirow{2}{*}{ Genetic parameters $\$$} & \multicolumn{10}{|c|}{--Number of harvests---- } \\
\hline & 1 & 2 & 3 & 4 & 5 & 6 & 7 & 8 & 9 & 10 \\
\hline$h_{i m}^{2}$ & 0.73 & 0.79 & 0.82 & 0.83 & 0.84 & 0.84 & 0.84 & 0.85 & 0.85 & 0.85 \\
\hline$R_{g}^{2}$ & 0.70 & 0.82 & 0.88 & 0.90 & 0.92 & 0.93 & 0.94 & 0.95 & 0.95 & 0.96 \\
\hline $\mathrm{AC}_{\text {clon }}$ & 0.86 & 0.89 & 0.90 & 0.91 & 0.91 & 0.92 & 0.92 & 0.92 & 0.92 & 0.92 \\
\hline Efficiency $^{\#}$ & 1.00 & 1.08 & 1.11 & 1.13 & 1.14 & 1.15 & 1.15 & 1.16 & 1.16 & 1.16 \\
\hline
\end{tabular}

\footnotetext{
${ }^{\$} h_{i m}^{2}$ : individual heritability based on harvest averages; $R_{g}^{2}$ : coefficient of genotypic determination. ${ }^{\#}$ Efficiency was calculated as the ratio between the estimated accuracy of $m_{i}$ harvest and the accuracy for a single harvest (for $\mathrm{i}=1, \ldots, 10$ ).
} 
Table 3 - Genotypic values (GV) and harmonic mean of the relative performance of genotypic values (RPGV) for processed coffee grain yield (bags.ha ${ }^{-1}$ ) of Conilon coffee clones, during the cropping seasons in 2014, 2015 and 2016, in the municipality of Ouro Preto do Oeste - RO.

\begin{tabular}{|c|c|c|c|c|c|}
\hline Order & Clone & $\mathrm{GV}_{2014}$ & $\mathrm{GV}_{2015}$ & $\mathrm{GV}_{2016}$ & RPGV \\
\hline 1 & 16R1C81 & 51.9 & 87.1 & 96.0 & 1.78 \\
\hline 2 & 535 & 61.0 & 71.4 & 92.7 & 1.73 \\
\hline 3 & 78 & 61.4 & 56.7 & 106.9 & 1.61 \\
\hline 4 & 167 & 48.9 & 105.1 & 61.5 & 1.61 \\
\hline 5 & 130 & 53.9 & 87.6 & 70.2 & 1.65 \\
\hline 6 & 453 & 47.9 & 87.0 & 74.1 & 1.61 \\
\hline 7 & 890 & 49.1 & 97.7 & 57.1 & 1.54 \\
\hline 8 & 482 & 68.1 & 59.3 & 72.2 & 1.54 \\
\hline 9 & 193 & 43.0 & 84.5 & 71.5 & 1.51 \\
\hline 10 & 194 & 39.2 & 91.2 & 65.5 & 1.45 \\
\hline 11 & 160 & 42.0 & 77.9 & 74.4 & 1.48 \\
\hline 12 & 909 & 51.2 & 65.6 & 72.8 & 1.48 \\
\hline 13 & 533 & 54.7 & 69.5 & 63.4 & 1.48 \\
\hline$\ldots$ & $\ldots$ & $\ldots$ & $\ldots$ & $\ldots$ & $\ldots$ \\
\hline 26 & 57 & 40.0 & 60.0 & 75.9 & 1.33 \\
\hline$\ldots$ & $\ldots$ & $\ldots$ & $\ldots$ & $\ldots$ & $\ldots$ \\
\hline 39 & 9R1C82 & 37.2 & 86.9 & 38.4 & 1.16 \\
\hline$\ldots$ & $\ldots$ & $\ldots$ & $\ldots$ & $\ldots$ & $\ldots$ \\
\hline 117 & 8R1C3U & 16.5 & 29.2 & 13.5 & 0.43 \\
\hline Average & - & 33.80 & 52.6 & 41.2 & - \\
\hline
\end{tabular}

the clones were selected (Table 4). Genetic gains from selection of superior plants of C. canephora were also obtained in the state of Espírito Santo (FERRÃO et al., 2008, DALCOMO et al., 2008) and Rondônia (RAMALHO et al., 2016). CONCLUSION

Predominance of the genetic component

Table 4 - Estimated genotypic values $(\mu+\mathrm{g})$ and selection gains in processed coffee grain yield (bags.ha $\left.{ }^{-1}\right)$ with $10 \%, 20 \%$ or $30 \%$ of 130 Conilon coffee clones evaluated during the cropping seasons in 2014, 2015 and 2016, in Porto Velho - RO.

\begin{tabular}{|c|c|c|c|c|c|c|}
\hline Order & Clone & $\mathrm{g}$ & $\mu+g$ & New average & Genetic gain & Genetic gain $(\%)$ \\
\hline 1 & 16R1C81 & 32.12 & 74.70 & 74.70 & 32.12 & 75.46 \\
\hline 2 & 535 & 29.10 & 71.68 & 73.19 & 30.61 & 69.45 \\
\hline 3 & 167 & 28.46 & 71.04 & 72.47 & 29.90 & 67.94 \\
\hline 4 & 78 & 28.27 & 70.84 & 72.06 & 29.49 & 67.34 \\
\hline 5 & 130 & 27.52 & 70.09 & 71.67 & 29.10 & 65.91 \\
\hline 6 & 453 & 24.49 & 67.06 & 70.90 & 28.33 & 61.04 \\
\hline 7 & 890 & 23.35 & 65.92 & 70.19 & 27.62 & 58.96 \\
\hline 8 & 194 & 22.18 & 64.75 & 69.51 & 26.94 & 56.92 \\
\hline 9 & 482 & 21.64 & 64.22 & 68.92 & 26.35 & 55.74 \\
\hline 10 & 160 & 21.58 & 64.15 & 68.44 & 25.87 & 55.21 \\
\hline 11 & 193 & 21.57 & 64.14 & 68.05 & 25.48 & 54.82 \\
\hline 12 & 909 & 18.54 & 61.11 & 67.48 & 24.90 & 50.89 \\
\hline 13 & 533 & 18.07 & 60.64 & 66.95 & 24.38 & 49.88 \\
\hline$\ldots$ & $\ldots$ & $\ldots$ & $\ldots$ & $\ldots$ & $\ldots$ & $\ldots$ \\
\hline 26 & 57 & 14.54 & 57.11 & 62.68 & 20.11 & 41.77 \\
\hline$\ldots$ & $\ldots$ & $\ldots$ & $\ldots$ & $\ldots$ & $\ldots$ & $\ldots$ \\
\hline 39 & 553 & 10.64 & 53.22 & 60.14 & 17.57 & 35.50 \\
\hline
\end{tabular}

$\mu$ : genotypic mean of processed coffee grain yield $\left(\right.$ bags.ha $\left.^{-1}\right)$; g: genotypic effect. 
was observed for all harvests evaluated. However, the predominant environmental variation should be considered in the joint evaluation of all harvests. The genetic progress for processed coffee yield was of $49.88 \%$ using the $10 \%$ best clones, resulting in an increase of the overall average yield for the three harvests from 42.57 bags.ha ${ }^{-1}$ to 66.95 bags.ha $^{-1}$. Clones were selected which maintained their genetic superiority with high accuracy (0.90) and determination $(0.88)$ over three agricultural years. The RPGV procedure, together with genetic gain selected Conilon coffee clones with superior performance, stability and adaptability.

\section{ACKNOWLEDGEMENTS}

The authors thank to the Conselho Nacional de Desenvolvimento Científico e Tecnológico (CNPq) for the scholar ship grant. We also gratefully acknowledge the Consórcio Brasileiro de Pesquisa e Desenvolvimento do Café (CPC) for financial support.

\section{REFERENCES}

BATISTA-SANTOS, P., et al. The impact of cold on photosynthesis in genotypes of Coffea spp.- photosystem sensitivity, photoprotective mechanisms and gene expression. Journal of plant physiology, v.168, n.8, p.792806. 2011. Available from: <https://doi.org/10.1016/j. jplph.2010.11.013>. Acessed: Oct.17, 2017.

BERTHAUD, J.; CHARRIER, A. Genetic resources of Coffea. In: CLARCK, R.J. AND MACRAE, R. (eds). Coffee - Agronomy. London, Elsevier Applied Science, p.1-40. 1985.

CONAB - COMPANHIA NACIONAL DE ABASTECIMENTO. Acompanhamento de safra brasileira de Café, v. 4 - Safra 2017, n.1 - Primeiro Levantamento, Brasília, p. 1-98, jan. 2017. Available from: <http://www.conab.gov.br>. Accessed: Oct. 17, 2017.

CRUZ, C. D.; CARNEIRO, P. C. S.; REGAZZI, A. J. Modelos biométricos aplicados ao melhoramento genético. 3 . ed. Viçosa: Universidade Federal de Viçosa, 2014. 668 p.

DALCOMO, J., et al. Evaluation of genetic divergence among clones of conilon coffee after scheduled cycle pruning. Genetics and Molecular Research, v.14, p.15417-15426. 2015. Available from: <http://dx.doi.org/10.4238/2015>. Accessed: Oct. 17, 2017

DUBBERSTEIN, D., et al. Dry matter in fruits, leaves and plagiotropic branches of grow coffee trees in the Western Amazon. Coffee Science, v.12, p.74-81, 2017. Available from: <http:// dx.doi.org/10.25186/cs.v12i1.1241>. Accessed: Oct. 17, 2017.

FERRÃO, R. G., et al. Genetic parameters in Conilon coffee. Pesquisa Agropecuária Brasileira, v.43, n.1, p.61-69. 2008. Available from: <http://dx.doi.org/10.1590/S0100204X2008000100009>. Accessed: Oct. 17, 2017.

FONSECA, A. F. A. D. et al. Repeatability and number of harvests required for selection in robusta coffee. Crop Breeding and Applied Biotechnology, v. 4, p. 325-329, 2004. Available from: <http://dx.doi.org/10.12702/1984-7033.v04n03a10>. Accessed: Oct. 17, 2017.

MARCOLAN, A. L. et al. Cultivo dos cafeeiros conilon e robusta para Rondônia. Porto Velho: Embrapa Rondônia, 2009. 67p. Available from: <http://www.sapc.embrapa.br/ arquivos/consorcio/publicacoes tecnicas/sp33-cafe.pdf $>$. Accessed: Oct. 17, 2017.

MONTAGNON, C., et al. Genotypic and phenotypic diversity of some coffee groups (Coffea canephora) in the collections. Consequences on their use in breeding. Café Cacao Thé, v.36, n.3, p.187 - 198, 1992. Available from: <http://agris.fao.org/>. Accessed: Oct. 17, 2017.

PARTELLI, F., et al. Characterization of the main lipid components of chloroplast membranes and cold induced changes in Coffea spp. Environmental and Experimental Botany, v.74, p.194-204. 2011. Available from: <https://doi.org/10.1016/j. envexpbot.2011.06.001>. Accessed: Oct. 17, 2017.

RAMALHO, A. R., et al. Genetic gain in the productivity of processed coffee from the selection of clones of 'Conilon' coffee. Revista Ciência Agronômica, v.47, n.3, p.516. 2016. Available from: <http://dx.doi.org/10.5935/1806-6690.20160062>. Accessed: Oct. 17, 2017.

RAMALHO, J., et al. Cold impact and acclimation response of Coffea spp. plants. Theoretical and Experimental Plant Physiology, v.26, n.1, p.5-18. 2014. Available from: < https://doi. org/10.1007/s40626-014-0001-7>. Accessed: Oct. 17, 2017.

RESENDE, M. D. V. Genética biométrica e estatística no melhoramento de plantas perenes: Embrapa Informação Tecnológica, Colombo: Embrapa Florestas. 2002

RESENDE, M. D. V.; J. B. DUARTE. Precision and quality control in variety trial. Pesquisa Agropecuária Tropical, v.37, n.3, p.182-194. 2007. Available from: <https://www.revistas.ufg. br/pat/article/view/1867>. Accessed: Oct. 17, 2017.

ROCHA, R. B., et al. Adaptability and stability of Coffea canephora coffee bean yield. Ciência Rural, v.45, n.9, p.15311537. 2015. Available from: <http://dx.doi.org/10.1590/01038478cr20141554>. Accessed: Oct. 17, 2017.

RODRIGUES WP, et al. Assessment of genetic divergence among coffee genotypes by Ward-MLM procedure in association with mixed models. Genetics and Molecular Research, v.15.n.2, p.1-7, 2016. Available from: <http://dx.doi.org/10.4238/ gmr.15027889>. Accessed: Oct. 17, 2017.

SANTOS, A. V., et al. Reaction of Coffea canephora clones to the root knot nematode, Meloidogyne incognita. African Journal of Agricultural Research, v.12, n.11, p.916-922. 2017. Available from: <http://dx.doi.org/10.5897/AJAR2016.11999>. Accessed: Oct. 17, 2017.

SOUZA, F. F., et al. Molecular diversity in Coffea canephora germplasm conserved and cultivated in Brazil. Crop breeding and applied biotechnology, v.13, n.4, p.221-227. 2013. Available from: <http://dx.doi.org/10.1590/S1984-70332013000400001>. Accessed: Oct. 17, 2017.

SOUZA, F. F., et al. Aspectos gerais da biologia e da diversidade genética de Coffea canephora. (Ed.). 
Café na Amazônia. Brasília, DF: Embrapa, 2015. Cap.4 p.85-95. Available from: <http://www.sapc.embrapa.br/ arquivos/consorcio/publicacoes_tecnicas/Livro_Cafe_na_ Amazonia_2015.pdf>.Accessed: Ōct. 17, 2017.

SOUZA, C. A., et al. Genetic components for fruit development and ripening of Coffea canephora Pierre ex A. Froehner. Coffee Science, v.12, n.3, p.355-364. 2017.
Available from: <http://dx.doi.org/10.25186/cs.v12i3.1295>. Accessed: Oct. 17, 2017.

VENCOVSKY, R., et al. Contribution and perspectives of quantitative genetics to plant breeding in Brazil. Crop Breeding and Applied Biotechnology, v.12, n.2, 2012. Available from: $<$ http://dx.doi.org/10.1590/S1984-70332012000500002>. Accessed: Oct. 17, 2017. 